\title{
Utilization of Plant Extracts for Managing Fruit Borers in Okra, [Abelmoschus esculentus (L.) Moench]
}

\author{
K.B. Subbireddy ${ }^{1}$, H.P. Patel ${ }^{2}$, N.B. Patel ${ }^{3 *}$ and T.M. Bharpoda ${ }^{4}$ \\ ${ }^{1}$ Department of Entomology, ${ }^{4}$ Department of Entomology, \\ B. A. College of Agriculture, AAU, Anand (Gujarat), India \\ ${ }^{2}$ Main Pulse Research Station, AAU, Vadodara (Gujarat), India \\ ${ }^{3}$ Tribal Research-cum-Training Centre, AAU, Devgadhbaria (Gujarat), India
}

\begin{tabular}{l} 
Ke y w o r d s \\
$\begin{array}{l}\text { Okra, Bio-efficacy, } \\
\text { Fruit borers and } \\
\text { plant extracts }\end{array}$ \\
\hline Article Info \\
$\begin{array}{l}\text { Accepted: } \\
\text { 20 April } 2018 \\
\text { Available Online: } \\
\text { 10 May } 2018\end{array}$ \\
\hline
\end{tabular}

Keywords

Okra, Bio-efficacy,

Fruit borers and

plant extracts

Article Info

20 April 2018

10 May 2018

\section{A B S T R A C T}

A field experiment was conducted to study the bio efficacy of seven plant extracts viz., neem oil $0.3 \%$, neem seed kernel extract 5\%, azadirachtin 0.15 EC $0.0006 \%$, Aloe vera extract $1 \%$, Citrulluscolo cynthis leaf extract $1 \%$, garlic bulb extract $3 \%$ and neem leaf extract 10\% against fruit borers during summer and kharif, 2016 at Main Vegetable Research Station, Anand Agricultural University, Anand (Gujarat). Among seven different plant extracts tested, neem oil $0.3 \%$ and azadirachtin 0.15 EC $0.0006 \%$ observed with lowest number of larvae and per cent fruit damage followed by NSKE 5\% and garlic bulb extract 3\% during both the seasons, while remaining plant extracts i.e. Aloe vera extract $1 \%$ and Citrulluscolo cynthis leaf extract $1 \%$ found poor to manage fruit borers. The highest marketable okra fruits were recorded from the plots treated with azadirachtin 0.15 EC $0.0006 \%$ (55.60 and $116.41 \mathrm{q} / \mathrm{ha}$ ) and neem oil $0.3 \%$ (52.58 and $118.25 \mathrm{q} / \mathrm{ha})$ followed by NSKE $5 \%$ (50.80 and $111.89 \mathrm{q} / \mathrm{ha}$ ) during summer and kharif season, respectively.

\section{Introduction}

Okra [Abelmoschus esculentus (L.) Moench] is an annual vegetable belonging to malvaceae family; it is also known by different names viz., ladies finger, bhindi, bamia, okro or gumbo in different parts of the world. Okra is valued for its tender green fruits. It is cooked in a variety of ways and used as an ingredient in a wide variety of dishes. Young tender leaves are used as a leafy vegetable in some parts of the world. The ripe seeds are roasted, ground and used as substitute for coffee in Turkey (Mehta, 1959). The roots and stem are used for clearing the cane juice from which gur or brown sugar is prepared (Chauhan, 1972). Its medicinal value has also been reported in curing ulcer and relief from haemorrhoids (Adams, 1975). The total area and production under okra in the world is reported to be 1.26 million ha and 22.29 million tonnes, respectively (Anonymous, 2017). It is mainly grown in India, Nigeria, Sudan, Pakistan, Ghana, Egypt, Saudi Arabia, Mexico and Cameroon. India ranks first in area and production which followed by Nigeria. In India, it is grown in an area of 0.50 million ha with an annual production of 5.98 
million tonnes. West Bengal is the leading producer followed by Bihar (Anon., 2017). One of the important limiting factors in the cultivation of okra is insect pests. Many of the pests occurring on cotton are found to ravage okra crop. As high as 72 species of insects have been recorded on okra (Srinivas and Rajendran, 2003), among them fruit borers like Earias spp. and Helicoverpa armigera cause significant damage to crop to the tune of 91.60 per cent (Pareek and Bhargava, 2003). The fruit borers are alone reported to cause damage to the extent of 3.5 to 90 per cent to okra in different parts of the country (Srinivasan and Narayanaswamy, 1960; Rawat and Sahu, 1973; Krishnaiah et al., 1976; Srinivasan and Krishnakumar, 1983; Chaudhary and Dadheech, 1989; Mandal et al., 2006). In general, the overall damage due to insect pests accounts to 48.97 per cent loss in fruit yields (Kanwar and Ameta, 2007). Attempts to control the pests by insecticides generally results in resistance, secondary outbreak, phytotoxicity, toxicity to beneficial organisms and residues in food which cause health hazards to the consumers. Moreover, in crops such as okra, the short interval between picking of fruits poses the residue hazards to the consumers when the chemical insecticides are used. The escalating concern towards environmental security and global stipulation for pesticide residue free food has induced intense interest for organic farming. Although use of insecticides cannot be altogether omitted as they form the mainstay of pest management strategies, yet their role can indubitably be limited by utilizing safer techniques of pest management such as biopesticides (plant derivatives and microbial insecticides), growing of pest tolerant/ resistant varieties and utilizing bio agents in an eco-friendly integrated pest management package. By considering all the above statements, present study was objectified to evaluate different plant extracts against fruit borers.

\section{Materials and Methods}

To study the bio-efficacy of plant extracts (Table 1) against fruit borers, a field experiment was laid out in Randomized Block Design with three replications having gross plot size of $6.0 \times 3.0 \mathrm{~m}$ and net plot size of 4.8 x $2.4 \mathrm{~m}$, respectively. There were eight treatments including control (Table 1). Okra, GAO-5 seeds were sown at a distance of 60 $\mathrm{cm}$ between two rows and $30 \mathrm{~cm}$ within the rows in the third week of March and last week of June during summer and kharif, 2016, respectively at Main Vegetable Research Station, Anand Agricultural University, Anand (Gujarat).

The recommended agronomical practices were followed to raise the crop. Treatment-wise application of plant extracts was given at ETL of fruit damage due to $H$. armigera or $E$. vittella (i.e. 5\% fruit damage) by using high volume knapsack sprayer with required concentration. Subsequent spray was given on need based during both the seasons of experimentation. The observations on larval population of $E$. vittella and $H$. armigera were recorded from five randomly selected plants per treatment by replication-wise before spray as well as 3, 7, 10 and 15 days after each sprays. The observations on fruit damage due to $H$. armigera and $E$. vitella was recorded at each picking by counting the healthy and damaged fruits from net plot area on number as well as weight basis and per cent fruit damage was worked out by using the following formula. The yield of marketable okra fruits from each treatment was recorded at each picking separately. The yield obtained from net plot area was converted into quintal per hectare.

$\%$ Fruit infestation

Number of damaged fruits

$($ Number basis $)=$ Total number of fruits 
$\%$ Fruit infestation

Weight of damaged fruits

(Weight basis) $=$

Total weight of fruits

\section{Statistical analysis}

The data on number of larva (e) per plant and per cent fruit damage were subjected to square root and arcsine transformation, respectively and statistically analysed by ANOVA and means were separated using LSD test at 5\% level of significance for interpretation by following standard statistical technique (Steel and Torrie, 1980).

\section{Results and Discussion}

\section{Fruit damage}

During summer, 2016 azadirachtin 0.15 EC (4.20\%) was found significantly superior and most effective in reducing the fruit damage on number basis, it was on par with neem oil and NSKE by recording 4.39 and 4.50 per cent fruit damage, respectively.

On weight basis (Table 1) results showed that azadirachtin $0.15 \mathrm{EC}$, neem oil and NSKE found equally effective by recording fruit weight losses of $4.11,4.29$ and 4.38 per cent, respectively.

The treatments of garlic bulb extract $(6.37 \%)$ and neem leaf extract $(6.47 \%)$ emerged as next better botanical pesticides. Of the evaluated botanical pesticides, Aloe vera and Citrulluscolo cynthis leaf extract treated plots recorded higher weight losses of 7.66 and $7.80 \%$, respectively.

Pooled over sprays during kharif season results are presented in Table 1. Lowest per cent fruit damage on number basis was observed in neem oil treated plots (5.47\%) and it was on par with azadirachtin (5.57\%) followed by NSKE (6.11\%). On weight basis, neem oil $(5.36 \%)$ followed by azadirachtin $(5.46 \%)$.

The treatment NSKE exhibited the weight loss of 6.02 per cent and stood next to aforesaid treatments. Whereas, maximum weight losses was noticed in Aloe vera extract $(9.59 \%)$ and Citrulluscolo cynthis leaf extract $(9.67 \%)$ and proved as least effective for managing fruit borers.

\section{Larval population}

\section{H. armigera}

The pooled data over sprays during summer season exposed higher effectiveness of azadirachtin (0.99 larva/plant) and it was at par with neem oil and NSKE which registered the larval population of 1.01 and 1.05, respectively and they were significantly superior to all the tested botanical pesticides.

During kharif, 2016 (Table 2), neem oil (1.82 larvae/plant) and azadirachtin 0.15 EC (1.88 larvae/plant) were found more effective in controlling $H$. armigera in okra, whereas NSKE was found next better treatment by recording 2.29 larvae per plant.

\section{E. vittella}

The larval population during summer, 2016 (Table 2) revealed that azadirachtin $0.15 \mathrm{EC}$ (1.33 larvae/plant), neem oil (1.49 larvae/plant) and NSKE (1.51 larvae/plant) were found significantly more effective than all the plant extracts evaluated in respect to their larvicidal efficacy on E. vittella.

Whereas, the highest pest population was noticed in Aloe vera extract (2.92 larvae/plant) and Citrulluscolo cynthis leaf extract (2.98 larvae/plant) and proved as less effective to $E$. vittella. 
Table.1 Bio-efficacy of plant extracts against fruit borers in okra during summer and khorif, 2016

\begin{tabular}{|c|c|c|c|c|c|c|c|}
\hline \multirow[t]{3}{*}{ Treatments } & \multirow{3}{*}{$\begin{array}{l}\text { Conc. } \\
(\%)\end{array}$} & \multirow{2}{*}{\multicolumn{2}{|c|}{$\begin{array}{c}\text { Summer } \\
\text { *Fruit damage }(\%)\end{array}$}} & \multirow{3}{*}{$\begin{array}{l}\text { Yield } \\
\text { (q/ha) }\end{array}$} & \multirow{2}{*}{\multicolumn{2}{|c|}{$\begin{array}{c}\text { Kharif } \\
\text { *Fruit damage }(\%)\end{array}$}} & \multirow{3}{*}{$\begin{array}{l}\text { Yield } \\
\text { (q/ha) }\end{array}$} \\
\hline & & & & & & & \\
\hline & & $\begin{array}{l}\text { Number } \\
\text { basis }\end{array}$ & $\begin{array}{l}\text { Weight } \\
\text { basis }\end{array}$ & & $\begin{array}{l}\text { Number } \\
\text { basis }\end{array}$ & $\begin{array}{l}\text { Weight } \\
\text { basis }\end{array}$ & \\
\hline Neem oil & 0.3 & $\begin{array}{l}12.09 \mathrm{a} \\
(4.39)\end{array}$ & $\begin{array}{l}11.95 \mathrm{a} \\
(4.29)\end{array}$ & $52.58 \mathrm{ab}$ & $\begin{array}{l}13.53 \mathrm{a} \\
(5.47)\end{array}$ & $\begin{array}{l}13.38 \mathrm{a} \\
(5.36)\end{array}$ & $118.25 \mathrm{a}$ \\
\hline $\begin{array}{l}\text { Neem seed kernel } \\
\text { extract }\end{array}$ & 5 & $\begin{array}{l}12.25 \mathrm{a} \\
(4.50)\end{array}$ & $\begin{array}{l}12.08 \mathrm{a} \\
(4.38)\end{array}$ & $50.80 \mathrm{abc}$ & $\begin{array}{l}14.31 b \\
(6.11)\end{array}$ & $\begin{array}{l}14.20 b \\
(6.02)\end{array}$ & $111.89 \mathrm{ab}$ \\
\hline Azadirachtin 0.15 EC & 0.0006 & $\begin{array}{l}11.82 \mathrm{a} \\
(4.20)\end{array}$ & $\begin{array}{l}11.70 \mathrm{a} \\
(4.11)\end{array}$ & $55.60 \mathrm{a}$ & $\begin{array}{l}13.66 \mathrm{ab} \\
(5.57)\end{array}$ & $\begin{array}{c}13.52 \mathrm{ab} \\
(5.46)\end{array}$ & $116.41 \mathrm{ab}$ \\
\hline Aloe vera extract & 1 & $\begin{array}{l}16.21 \mathrm{c} \\
(7.79)\end{array}$ & $\begin{array}{l}16.07 \mathrm{c} \\
(7.66)\end{array}$ & $33.71 d$ & $\begin{array}{l}18.14 d \\
(9.69)\end{array}$ & $\begin{array}{l}18.04 d \\
(9.59)\end{array}$ & $74.56 \mathrm{~cd}$ \\
\hline $\begin{array}{l}\text { Citrulluscolo cynthis } \\
\text { leaf extract }\end{array}$ & 1 & $\begin{array}{l}16.32 \mathrm{c} \\
(7.90)\end{array}$ & $\begin{array}{l}16.21 \mathrm{c} \\
(7.80)\end{array}$ & $32.55 d$ & $\begin{array}{l}18.21 \mathrm{~d} \\
(9.77)\end{array}$ & $\begin{array}{l}18.12 d \\
(9.67)\end{array}$ & $73.88 \mathrm{~cd}$ \\
\hline Garlic bulb extract & 3 & $\begin{array}{l}14.75 b \\
(6.48)\end{array}$ & $\begin{array}{l}14.62 b \\
(6.37)\end{array}$ & $41.17 \mathrm{bcd}$ & $\begin{array}{l}16.62 \mathrm{c} \\
(8.18)\end{array}$ & $\begin{array}{l}16.53 c \\
(8.09)\end{array}$ & $93.02 \mathrm{abc}$ \\
\hline Neem leaf extract & 10 & $\begin{array}{l}14.84 b \\
(6.56)\end{array}$ & $\begin{array}{l}14.74 b \\
(6.47)\end{array}$ & $39.66 \mathrm{~cd}$ & $\begin{array}{l}16.66 \mathrm{c} \\
(8.22)\end{array}$ & $\begin{array}{l}16.55 c \\
(8.11)\end{array}$ & $92.55 b c$ \\
\hline Untreated control & - & $\begin{array}{l}17.81 d \\
(9.36)\end{array}$ & $\begin{array}{c}17.72 d \\
(9.27)\end{array}$ & $19.67 \mathrm{e}$ & $\begin{array}{c}19.49 \mathrm{e} \\
(11.14)\end{array}$ & $\begin{array}{c}19.42 \mathrm{e} \\
(11.06)\end{array}$ & $57.33 d$ \\
\hline S.Em. \pm & & 0.33 & 0.34 & 3.59 & 0.26 & 0.26 & 7.65 \\
\hline C. V. $(\%)$ & & 9.79 & 9.88 & 15.26 & 9.66 & 9.70 & 14.37 \\
\hline
\end{tabular}


Table.2 Bio-efficacy of ready-mix insecticides against fruit borers in okra during summer and kharif, 2016

\begin{tabular}{|c|c|c|c|c|c|}
\hline \multirow[t]{3}{*}{ Treatments } & \multirow{3}{*}{$\begin{array}{c}\text { Conc. } \\
(\%)\end{array}$} & \multicolumn{4}{|c|}{ *Number of larva/ plant } \\
\hline & & \multicolumn{2}{|c|}{ Summer } & \multicolumn{2}{|c|}{ Kharif } \\
\hline & & H. armigera & E. vittella & H. armigera & E. vittella \\
\hline Neem oil & 0.3 & $\begin{array}{c}1.23 \mathrm{a} \\
(1.01)\end{array}$ & $\begin{array}{c}1.41 \mathrm{a} \\
(1.49)\end{array}$ & $\begin{array}{l}1.52 \mathrm{a} \\
(1.82)\end{array}$ & $\begin{array}{c}1.16 a \\
(0.85)\end{array}$ \\
\hline Neem seed kernel extract & 5 & $\begin{array}{c}1.25 \mathrm{a} \\
(1.05)\end{array}$ & $\begin{array}{c}1.42 \mathrm{a} \\
(1.51)\end{array}$ & $\begin{array}{l}1.67 b \\
(2.29)\end{array}$ & $\begin{array}{l}1.27 b \\
(1.12)\end{array}$ \\
\hline Azadirachtin 0.15 EC & 0.0006 & $\begin{array}{l}1.22 \mathrm{a} \\
(0.99)\end{array}$ & $\begin{array}{c}1.35 \mathrm{a} \\
(1.33)\end{array}$ & $\begin{array}{c}1.54 \mathrm{a} \\
(1.88)\end{array}$ & $\begin{array}{c}1.15 \mathrm{a} \\
(0.83)\end{array}$ \\
\hline Aloe vera extract & 1 & $\begin{array}{l}1.60 c \\
(2.06)\end{array}$ & $\begin{array}{l}1.85 c \\
(2.92)\end{array}$ & $\begin{array}{l}2.07 d \\
(3.77)\end{array}$ & $\begin{array}{l}1.63 d \\
(2.16)\end{array}$ \\
\hline Citrulluscolo cynthis leaf extract & 1 & $\begin{array}{l}1.62 \mathrm{c} \\
(2.13)\end{array}$ & $\begin{array}{l}1.87 \mathrm{c} \\
(2.98)\end{array}$ & $\begin{array}{l}2.09 d \\
(3.87)\end{array}$ & $\begin{array}{l}1.64 d \\
(2.19)\end{array}$ \\
\hline Garlic bulb extract & 3 & $\begin{array}{l}1.51 b \\
(1.78)\end{array}$ & $\begin{array}{l}1.70 \mathrm{~b} \\
(2.40)\end{array}$ & $\begin{array}{l}1.91 \mathrm{c} \\
(3.14)\end{array}$ & $\begin{array}{l}1.46 \mathrm{c} \\
(1.63)\end{array}$ \\
\hline Neem leaf extract & 10 & $\begin{array}{l}1.53 b \\
(1.84)\end{array}$ & $\begin{array}{l}1.72 b \\
(2.46)\end{array}$ & $\begin{array}{l}1.93 c \\
(3.23)\end{array}$ & $\begin{array}{c}1.47 \mathrm{c} \\
(1.67)\end{array}$ \\
\hline Untreated control & - & $\begin{array}{l}1.76 \mathrm{~d} \\
(2.60)\end{array}$ & $\begin{array}{l}1.99 \mathrm{~d} \\
(3.46)\end{array}$ & $\begin{array}{l}2.25 \mathrm{e} \\
(4.56)\end{array}$ & $\begin{array}{c}1.75 \mathrm{e} \\
(2.55)\end{array}$ \\
\hline S.Em. + & & 0.02 & 0.03 & 0.03 & 0.03 \\
\hline C. V. $(\%)$ & & 9.92 & 9.08 & 9.50 & 10.08 \\
\hline
\end{tabular}




\section{Yield}

The highest $(55.60 \mathrm{q} / \mathrm{ha})$ fruit yield of okra was obtained from the plots treated with azadirachtin $0.15 \mathrm{EC}$ and it was at par with neem oil (52.58 q/ha) and NSKE (50.80 q/ha) when compared with untreated plot (19.67 q/ha) during summer (Table 1). During kharif season, significantly highest (118.25 q/ha) fruit yield was obtained from the plots treated with neem oil followed by azadirachtin 0.15 EC (116.41 q/ha) and NSKE (111.89 q/ha).

On the basis of aforesaid experimental results, neem oil $0.3 \%$, azadirachtin $0.15 \mathrm{EC}$ and NSKE 5\% evolved as better plant extracts by registering minimum population of fruit borers as well as fruit damage. The effectiveness of these plant extracts as foliar spray against fruit borers noticed in present study is in agreement with the reports of Sardana and Kumar (1989), Sojitra and Patel (1992), Shukla et al., (1996), Senuguttuvan and Rajendran (2001), Mandal et al., (2007), Sahak and Lyall (2013) and Barakzai and Lyall (2014). All these workers have showed the effectiveness of neem oil against fruit borers. According to Sardana and Kumar (1989), neem oil proved to be the best in reducing the fruit borer damage in okra. Sojitra and Patel (1992) observed that the application of neem oil (1\%) provided good in reduction of $E$. vittella on okra. Four sprays of Achook (1\%) and neem oil (1\%) were provided good result to manage $E$. vittella in okra at Jabalpur, Madhya Pradesh (Shukla et al., 1996). Barakzai and Lyall (2014) reported that neem oil (1\%) proved effective against $E$. vittella i.e. 6.60 per cent fruit damage over 22.00 per in control with highest yield and CBR (80.43 q/ha and 2.59, respectively). As per the results of Mandal et al., (2007), the combination treatment comprising the soil application of neem cake at $200 \mathrm{~kg}$ per hectare along with three foliar sprays of neem oil @ $0.51 /$ ha recorded the lowest percentage of shoot and fruit borer damage and minimum borer population with maximum marketable okra fruits $(127.48 \mathrm{q} / \mathrm{ha})$ and proved profitable with the maximum cost benefit ratio 8.17. Similarly, Dhaka et al., (2016) Ayyangar and Rao (1989) and Sarkar et al., (2015) proved azadirachtin found to be good botanical insecticide to manage fruit boring pests in okra. According to Yadav et al., (2008), application of Bt-neem formulation with azadirachtin-endosulfan-Trichogramma at 15 days intervals reduced the fruit and shoot borer infestation up to $1.93 \%$ with the maximum yield $(79.70 \mathrm{q} / \mathrm{ha})$. Ayyangar and Rao (1989) have reported that azadirachtin played a major role in controlling the insect pests by adversely affecting the consumption and utilization of plant parts by the pests. In present study, NSKE 5\% proved as best plant extracts in controlling fruit boring pests in okra is corroborating with the findings of Senguttuvan and Rajendran (2001), who observed that the treatment of NSKE 5 per cent was superior by recording lower fruit damage $(11.3 \%)$ over untreated check (31.3\%). Present study concluded that, plots sprayed with neem oil $0.3 \%$ and azadirachtin 0.15 EC $0.0006 \%$ observed with lowest number of larvae and per cent fruit damage followed by neem seed kernel extract 5\% and obtained maximum fruit yield. By spraying these plant extracts when the pest population is at minimum will take care of pests and achieve the risk of residue problem and also should be able to incorporate in IPM programs.

\section{Acknowledgement}

Authors are highly thankful to Professor and Head, Department of Entomology and Research Scientist (Vegetable), Main Vegetable Research Station, Anand Agricultural University, Anand, Gujarat. For providing necessary facilities to conduct experiment. 


\section{References}

Adams, C.F. 1975. Nutritive value of American foods in common units. U. S. Department of Agriculture, Agriculture Handbook, No. 425, 29.

Anonymous. 2017. Horticultural statistics at a glance; http://nhb.gov.in.

Ayyangar, G.S.G. and Rao, P.J. 1989. Azadirachtin effects on consumption and utilization of food and midgut enzymes of Spodoptera litura Fab. Ind. J. Ent., 51(4): 373-376.

Barakzai, A.W. and Lyall, H. 2014. Efficacy of botanical insecticides in management of okra shoot and fruit borer, Earias vittella (Fab.). Ann. Pl. Prot. Sci., 22(2): 339-341.

Chaudhary, H. R. and Dadheech, L. N. 1989. Incidence of insects attacking okra and the avoidable losses caused by them. Ann. Arid Zone, 28(3-4): 305-307.

Chauhan, D.V.S. 1972. Vegetable production in India ( $3^{\text {rd }}$ ed.). Ram Prasad and Sons, Agra.

Dhaka, S.S., Rai, M.K. and Kumar, A. 2016. Relative efficacy of novel insecticides and biopesticides against Earias vittella (Fab.) in okra. Ann. Pl. Prot. Sci., 24(2): 271-275.

Kanwar, N. and Ameta, O.P. 2007. Assessment of loss caused by insect pests of okra [Abelmoschus esculentus (L.) Moench]. Pestology, 31(5): 45-47.

Krishnaiah, K., Tandon, P.L., Mathur, A.C. and Mohan, N.J. 1976. Evaluation of insecticides for the control of major insect-pests of okra. Ind. J. Agril. Sci., 46(4): 178-186.

Mandal, S.K., Sah, S.B. and Gupta, S.C. 2006. Efficacy and economics of biopesticide and insecticide combinations against okra pests. Int. J. Agril. Sci., 2(2): 377-380.

Mandal, S.K., Sah, S.B. and Gupta, S.C. 2007. Management of insect pests on okra with biopesticides and chemicals. Ann. Pl. Prot. Sci., 15(1): 87-91.

Mehta, Y.R. 1959. Vegetable growing in Uttar Pradesh. Rockefeller Foundations, Bureau of Agriculture Information. Lucknow, Utter Pradesh, India.

Pareek, B.L., and Bhargava, M.C. 2003. Estimation of avoidable losses in vegetable crops caused by borers under semi-arid conditions of Rajasthan. Insect Environment. 9: 59-60.

Rawat, R.R. and Sahu, H.R. 1973. Estimation of losses in growth and yield of okra due to Empoasca devastans Distant and Earias species. Ind. J. Ent., 35(3): 252254.

Rosaiah, R. 2000. Evaluation of different botanicals against the pest complex of brinjal. Pestology, 24: 17-19.

Sahak, K.A. and Lyall, H. 2013. Efficacy of chemical and plant products in management of Earias vittella Fab. on okra. Ann. Pl. Prot. Sci., 21(2), 283285.

Sardana, H.R. and Kumar, N.K. 1989. Effectiveness of plant oils against leafhopper and shoot and fruit borer on okra. Ind. J. Ent., 51(2): 167-171.

Sarkar, S., Patra, S. and Samanta, A. 2015. Evaluation of bio-pesticides against red cotton bug and fruit borer of okra. The Bioscan, 10(2): 601-604.

Senguttuvan, T. and Rajendran, R. 2001. Plant products for the control of bhendi fruit borers. In: proceedings of the second national symposium on integrated pest management in horticultural crops: New molecules, Biopesticides and Environment, Bangalore, Karnataka, India. pp. 17-18.

Shukla, A., Pathak, S.C. and Agarwal, R.K. 1996. Efficacy of some insecticides and plant products against the infestation of okra shoot and fruit borer, Earias vittella Fab. Crop Res., 12(3): 367-373. 
Sojitra, I.R. and Patel, J.R. 1992. Effect of plant extracts on ovipositional behaviour of spotted bollworm (Earias vittella) infesting okra. Ind. J. Agril. Sci., 62(12): 848-849.

Srinivas, R. and Rajendran, R. 2003. Joint action potential of neem with other plant extracts against the leaf hopper Amrasca devastans (Distant) on okra. Pest Manage. \& Econ. Zool., 10: 131136.

Srinivasan, K. and Krishnakumar, N.K. 1983. Studies on the extent of loss and economics of pest management in okra. Tropical Pest Manage., 29 (4): 363-370.
Srinivasan, P.M. and Narayanaswamy, P.S. 1960. Experiments on the control of shoot and fruit borer, Earias fabia and Earias insulana on bhendi. Madras Agril. J., 60: 601-602.

Steel, R.G.D. and Torrie, J.H. 1980. Principles and procedures of statistics. McGraw-Hill Book Company, New York.

Yadav, J.B., Singh, R.S. and Tripathi, R. A. 2008. Evaluation of bio-pesticides against pest complex of okra. Ann. Pl. Prot. Sci., 16(1): 58-61.

\section{How to cite this article:}

Subbireddy, K.B., H.P. Patel, N.B. Patel and Bharpoda, T.M. 2018. Utilization of Plant Extracts for Managing Fruit Borers in Okra, [Abelmoschus esculentus (L.) Moench]. Int.J.Curr.Microbiol.App.Sci. 7(05): 2786-2793. doi: https://doi.org/10.20546/ijcmas.2018.705.324 